\title{
KESEHARIAN ISTERI NELAYAN: STUDI ANTROPOLOGI TENTANG POLA NAFKAH PADA KOMUNITAS NELAYAN DI NAGARI TIKU SELATAN, KECAMATAN TANJUNG MUTIARA, KABUPATEN AGAM ${ }^{1}$
}

\author{
Hendrawati $i^{2}$, Lucky Zamzami ${ }^{3}$,Sri Meiyenti ${ }^{4}$, Yunarti ${ }^{5}$
}

\begin{abstract}
This article is the result of research on the role of women fishing households living systems. The contribution of women in household income earned through productive activities that they do. These activities, among them, is the involvement of women in the marketing of the fisheries and involvement in the processing of the fisheries. Small industries in rural apparently has a role in increasing the contribution of women in their household income.

Livelihood strategies undertaken by poor fishermen households consisting of economic strategies and social strategies. Economic strategy by performing a double living patterns, utilization of household labor and migration. While social strategy is done by utilizing the existing ties of kinship. Traditional welfare institutions also have an important role to poor households in meeting their needs. Social capital has an important role in the livelihood strategies of poor households in Nagari Tiku Selatan.
\end{abstract}

Keywords: Women fishing household, Income, Economis and Social Strategies

\section{A. Pendahuluan}

W ilayah pesisir pantai adalah wilayah yang dihuni oleh masyarakat dengan karakteristik keluarga yang khas dan didominasi oleh penduduk setiap harinya adalah wanita dan anak-anak. Sebagian lelaki yang terdiri dari suami maupun remaja, banyak mempergunakan waktunya untuk melaut. Pada umumnya kaum perempuan ditinggal melaut antara 12 minggu, sedangkan sisanya adalah nelayan biasa (melaut malam hari) dan sebagian lagi berlayar sampai sebulan atau lebih (ikut kapal besar), sehingga dapat dikatakan sebagian besar tanggungjawab kelangsungan hidup sehari-hari pada keluarga tersebut ada ditangan wanita sebagai ibu sekaligus ayah.

Kondisi ekonomi yang semakin tidak menentu yang dialami oleh bangsa Indonesia saat ini berdampak sangat luas dan memberatkan kehidupan masyarakat dari semua lapisan. Nelayan pada dasarnya harus menyesuaikan diri, antara lain dengan memanfaatkan anggota rumah tangga untuk bekerja sebagai upaya meningkatkan pendapatan keluarga nelayan. Upaya peningkatan pendapatan ini ditempuh melalui usaha produktivitas seluruh sumber daya manusia yang ada dalam keluarga nelayan. Diantara anggota keluarga nelayan yang produktif untuk menambah pendapatan adalah para isteri nelayan (Purwanti et.al, 2004).

Di Asia, kaum wanita mempunyai jam kerja yang panjang dari kaum pria, karena bekerja baik di dalam maupun di luar rumah (Todaro, 2000). Di samping berbagai pekerjaan tambahan, istri nelayan sebagai ibu rumah tangga tetap melaksanakan pekerjaan rutinnya, mengurus rumah tangga, mengasuh anak, memasak, mencuci dan lain-lain. Dari pengamatan fisik terlihat wajah istri nelayan lebih tua dari umurnya. Ini disebabkan keadaan alam, jenis pekerjaan kasar yang mereka lakukan, terpaan terik matahari yang menimpa wajah mereka dan kelengkapan gizi yang terbatas. Waktu merupakan sumber utama golongan

\footnotetext{
${ }^{1}$ Artikel ini merupakan hasil penelitian hibah dana fakultas ISIP tahun 2013

${ }^{2}$ Penulis adalah dosen tetap jurusan Antropologi FISIP Universitas Andalas, Padang

${ }^{3}$ Penulis adalah dosen tetap jurusan Antropologi FISIP Universitas Andalas, Padang

${ }^{4}$ Penulis adalah dosen tetap jurusan Antropologi FISIP Universitas Andalas, Padang

${ }^{5}$ Penulis adalah dosen tetap jurusan Antropologi FISIP Universitas Andalas, Padang
} 
luar rumah. Bila jam kerja tersebut dinilai secara ekonomis, maka kontribusi pendapatan kaum wanita dan anak-anaknya lebih besar dari pendapatan pria (Todaro, 2000). Dalam upaya memenuhi kebutuhan hidup, rumah tangga miskin menerapkan strategi ganda dimana suami, istri dan anak usia kerja terlibat mencari nafkah di dalam kegiatan perikanan dan luar perikanan sekaligus. Pola nafkah ganda itu lebih nyata di desa lahan pantai dibandingkan desa lahan kering, karena peluang kerja/usaha luar perikanan terbatas di pedesaan pantai khususnya bagi wanita.

Dalam konteks studi antropologi di Indonesia, kajian-kajian tentang wanita dalam pembangunan tampaknya telah banyak dibicarakan dalam berbagai penelitian/studi literatur. Peneliti antropologi banyak memusatkan penelitian kepada kajian peran dan status wanita dalam rumah tangga petani dan nelayan. Dalam konteks ini, kajian tentang wanita nelayan dalam hal ini isteri-isteri nelayan yang diungkapkan secara mendalam khususnya melalui kajian etnografi masih kurang. Dalam rentang perkembangan penelitian tersebut tentang peran dan status wanita nelayan, bukanlah hal yang baru untuk dibicarakan. Berbagai studi telah dilakukan seperti wanita berperan dalam ekonomi rumah tangga terutama di pedesaan pantai (Suhartini, 2012). Wanita begitu tangguh dalam memerankan peranannya ditengah-tengah masyarakat yang umumnya berperan ganda, baik sebagai ibu rumah tangga maupun sebagai wanita aktif/bekerja untuk menambah penghasilan keluarga yang dicintai menuju keluarga yang tercukupi sandang dan pangan (Wahyuni, 1993). Disamping itu, studi tentang peran wanita dalam pembangunan dan peran ganda dalam keluarga (Ihromi, 1990: hidayat, 2007: Suhartini, 2012), Wanita tidak hanya berperan sebagai ibu rumah tangga, tetapi juga melakukan kegiatan produktif guna menambah penghasilan. Peran wanita dari rumah tangga berpenghasilan rendah cenderung menggunakan lebih banyak waktu untuk kegiatan produktif dibandingkan dengan pekerjaan wanita dari rumah tangga berpenghasilan tinggi (Ihromi, 1990).

Penduduk wanita yang jumlahnya mencapai $60 \%$ dari jumlah total penduduk Indonesia merupakan sumber daya pembangunan yang cukup besar. Partisipasi aktif pria dan wanita dalam setiap proses pembangunan akan mempercepat tercapainya tujuan pembangunan. Persentase wanita yang lebih besar daripada laki-laki di Salah satu daerah yang menjadi sentral nelayan dan usaha kelautan di Sumatra Barat adalah Kabupaten Agam, tepatnya di Kecamatan Tanjung Mutiara. Masyarakat nelayan di daerah ini terpusat di nagari Tiku Selatan dan nagari Tiku $V$ Jorong. Nagari Tiku Selatan dan Tiku V Jorong merupakan kawasan pemukiman nelayan di Kecamatan Tanjung Mutiara. Kecamatan Tanjung Mutiara merupakan satu dari 16 kecamatan di Kabupaten Agam yang memiliki panjang pantai sekitar $43 \mathrm{~km}$, $27 \mathrm{~km}$ per segi terumbuk karang dan 65 hektare hutan manggrov. Jumlah Nelayan di nagari Tiku Selatan dan nagari Tiku $V$ Jorong, Kecamatan Tanjung Mutiara tercatat sekitar 1.952 orang dan aktif sekitar 1.750 orang dengan produksi ikan mencapai 3.415 ton/tahun dengan hasil tangkap jenis pelagis, udang dan teri (http://www.sumbarprov. go.id/index.php). Di wilayah tersebut, merupakan potensi untuk meningkatkan pendapatan masyarakat nelayan, dimana posisi wanita yang selama ini hanya berfungsi sebagai ibu rumah tangga ditingkatkan sebagai pencari nafkah.

\section{B. Permasalahan}

$\mathrm{P}$ erempuan nelayan yang selama ini dipandang sebagai isteri nelayan dan perannya mengurus rumah tangga, sesungguhnya memiliki ketangguhan dalam mengatasi persoalan ekonomi keluarga. Berbagai aktivitas dilakukan dengan menjadi buruh perikanan, mengembangkan usaha kecil dan sebagai pedagang keliling serta usaha-usaha kecil lainnya. Perempuan nelayan juga membangun modal sosial melalui usaha warungan, usaha bersama, koperasi atau credit union. Dari berbagai kegiatan ekonomi tersebut perempuan nelayan mampu membuka akses sumberdaya ekonomi informal yang mereka bangun sendiri karena keterbatasannya terhadap akses sumberdaya keuangan formal. Perempuan nelayan lebih dominan dalam membangun dan mengembangkan modal sosial karena bagi perempuan nelayan, pekerjaan mengurus rumah tangga dan pekerjaan yang berkaitan dengan ekonomi rumah tangga tidak dapat dipisahkan sebagai bagian dari keseluruhan tugasnya sehari-hari. Pekerjaan yang berkaitan dengan pertanian bagi perempuan merupakan bagian dari kegiatan sehari-hari, 
selain beban pekerjaan rumah tangga seperti mengurus anak, memasak, dan lain sebagainya (Astuti, 2007).

Dalam menghadapi situasi tersebut perempuan nelayan tidak tinggal diam tetapi bergerak secara aktif mencari solusi untuk mengatasi persoalan ekonomi rumah tangganya. Bahkan dapat dikatakan sebagai pencari nafkah tunggal disaat suami tidak dapat melaut. Dalam kondisi ini berbagai kegiatan produktif dilakukan perempuan nelayan seperti menjadi buruh membersihkan kerang, pengupas udang, pedagang keliling, berdagang pakaian bekas dan menjadi pemulung. Usaha lainnya yang dikembangkan adalah membuat kerupuk udang dan kerupuk ikan. Dengan membuat kerupuk maka persediaan ikan dan udang yang sangat terbatas dapat dikelola untuk periode produksi yang cukup panjang karena menggunakan bahan tambahan lain seperti tepung tapioka.

Dapat dikatakan bahwa perempuan nelayan memiliki multi peran yang dijalankan secara bersamaan yaitu peran dalam ranah reproduksi sosial dimana perempuan pesisir merupakan penjaga kelangsungan hidup sistem sosial masyarakat pesisir dan dalam ekonomi rumah tangga atau produksi serta membangun modal sosial.

Berdasarkan latar belakang tersebut diatas, maka penelitian ini akan melihat bagaimana keseharian isteri-isteri nelayan dalam pola nafkah ekonomi rumah tangga di nagari Tiku Selatan, Kecamatan Tanjung Mutiara, Kabupaten Agam.

\section{Tinjauan Pustaka}

W anita nelayan (isteri-isteri nelayan) dalam satu masyarakat nelayan hidup, tumbuh, dan berkembang sebagai satu kesatuan sosial di wilayah pesisir pantai. Dalam konstruksi sosial masyarakat di kawasan pesisir, wanita nelayan (isteri-isteri nelayan) merupakan bagian dari konstruksi sosial tersebut. Desadesa pesisir yang sebagian besar penduduknya bermatapencaharian sebagai nelayan, petambak, atau pembudidaya perairan, kebudayaan nelayan berpengaruh besar terhadap terbentuknya identitas kebudayaan masyarakat pesisir secara keseluruhan (Ginkel, 2007; Kusnadi, 2010; Zamzami, 2009, 2010). Nelayan, petambak, dan pembudidaya perairan merupakan kelompok-kelompok sosial yang langsung berhubungan dengan pengelolaan sumber daya pesisir dan kelautan.

Bagi masyarakat nelayan, kebudayaan merupakan sistem gagasan atau sistem kognitif yang berfungsi sebagai "pedoman kehidupan", referensi pola-pola kelakuan sosial, serta sebagai sarana untuk menginterpretasi dan memaknai berbagai peristiwa yang terjadi di lingkungannya (Keesing, 1989:68-69; Kusnadi, 2010). Setiap gagasan dan praktik kebudayaan harus bersifat fungsional dalam kehidupan masyarakat. Jika tidak, kebudayaan itu akan hilang dalam waktu yang tidak lama. Kebudayaan haruslah membantu kemampuan survival masyarakat atau penyesuaian diri individu terhadap lingkungan kehidupannya. Sebagai suatu pedoman untuk bertindak bagi warga masyarakat, isi kebudayaan adalah rumusan dari tujuan-tujuan dan cara-cara yang digunakan untuk mencapai tujuan itu, yang disepakati secara sosial (Kluckhon, 1984:8591, Kusnadi, 2010). Perspektif antropologis untuk memahami eksistensi suatu masyarakat bertitik tolak dan berorientasi pada hasil hubungan dialektika antara manusia, lingkungan, dan kebudayaannya. Karena itu, dalam beragam lingkungan yang melingkupi kehidupan manusia, satuan sosial yang terbentuk melalui proses demikian akan menampilkan karakteristik budaya yang berbeda-beda.

Dalam mengenal, merinci, dan menelaah masalah yang dihadapi wanita nelayan (isteri-isteri nelayan), ditegaskan beberapa asumsi pokok yang menganalisa peranan wanita di dalam keluarga, rumah tangga, dan masyarakat yang lebih luas, yang dikemukakan Sajogyo (2011) bahwa keluarga inti atau keluarga batih" sebagai kesatuan kerabat yang paling kecil dianggap kesatuan sosial yang paling relevan untuk menganalisa peranan wanita. Secara operasional, kesatuan "rumah tanggalah" yang tepat untuk kesatuan analisa itu. Kedua dasar tersebut menunjukkkan menelaah posisi atas status dalam "hubungan pria dan wanita". Adanya pelapisan dalam masyarakat nelayan termasuk sektor lainnya, berarti pula bahwa wanita pedesaan tidak dapat dianggap sebagai golongan yang seragam, dalam arti mempunyai ciri-ciri, kebutuhan dan persoalan yang sama. Di lain pihak, terdapat suatu kenyataan secara umum bahwa posisi wanita di desa-desa nelayan di Indonesia khususnya dan negara sedang 
berkembang pada umumnya, posisi mereka termarginalisasi. Scott (2008) mengatakan bahwa marginalisasi perempuan tumbuh dari kombinasi faktor sejarah, ekonomi, dan budaya, dalam arti luas, tidak hanya disebabkan oleh suatu sistem ekonomi politik tertentu.

Permasalahan pokok wanita dijelaskan oleh Santoso (2010): pertama, data mengenai tenaga kerja wanita di pedesaan, terdapat adanya norma bahwa wanita apakah sebagai istri, ibu rumah tangga atau anak gadis, mencari nafkah disamping pekerjaan rumah tangga. Kedua: waktu yang dicurahkan untuk pekerjaan rumah tangga adalah lebih intensif dan banyak. Ketiga: terhadap pekerjaan yang menghasilkan pendapatan, mereka mencurahkan waktu lebih banyak dengan hasil yang lebih rendah dari pria golongan sosial ekonomi yang sama. Keempat: pendidikan formal mereka lebih rendah dari pria golongan sosial ekonomi yang sama, sehingga keterampilannya juga lebih rendah. Kelima: kurangnya jangkauan pelayanan, khususnya wanita yang tidak mampu, yang menyebabkan mengecilnya pengaruh mereka dalam proses "pengambilan keputusan" dalam keluarga khususnya, di masyarakat pada umumnya. Selanjutnya Scott mengidentifikasi empat dimensi marginalisasi wanita : (1). Penyingkiran wanita dalam semua bentuk partisipasi wanita dalam angkatan kerja yang menghasilkan upah atau nilai tambah. (2). Terpinggirnya wanita pada sektor informal yang tidak memiliki kestabilan kerja, upah rendah, dan kondisi kerja kurang baik. (3). Penurunan rasio wanita dalam setiap jabatan pada sektor "produktif tertentu". (4). Pelebaran ketimpangan ekonomi antara pria dan wanita.

Temuan Scott tersebut dipertegas oleh Suratiyah (2008): acapkali masyarakat memandang bila dalam keluarga, dimana suami istri bekerja di dunia publik dan terjadi keretakan dalam kehidupan keluarganya, maka wanitalah segala bentuk kesalahan ditimpakan. Budiman (2010) menyatakan bahwa terdapat suatu kecenderungan, setiap kali wanita bekerja dan mengembangkan diri serta karirnya di dunia publik, mereka harus menyelesaikan dahulu pekerjaan rumah tangganya. Apa yang dikemukakan oleh Budiman itu menunjukkan bahwa apabila wanita ingin mengembangkan diri di masyarakat atau karirnya di dunia publik, mereka dituntut tidak melupakan tugas mereka sebagai seorang ibu rumah tangga. Bronstein (2009) menunjukkan bagaiman wanita dari keluarga miskin di pedesaan acapkali harus menderita karena "triple strugle" (perjuangan rangkap tiga) yang meliputi : (1). Sebagai warga negara terbelakang, (2). Sebagai petani yang tinggal di pedesaan yang sangat miskin, dan (3). sebagai wanita yang hidup di tengah dominasi masyarakat pria. Beneria (2009) memperkuat pendapat Bronstein dengan mengatakan bahwa sebagian besar masyarakat dunia ketiga sudah lazim terjadi pembagian kerja seksual. Laki-laki pada umumnya ditempatkan dalam posisi dominan sebagai pencari nafkah (Bread Winner), sedangkan wanita sebagai nyonya rumah (Home Marker) yang bertanggung jawab atas kegiatan reproduktif dan domestik. Namun, terdapat konsep yang bersifat spesifik pada studi perempuan, yaitu: feminisasi (feminization), pengiburumahtanggaan (housewifization) dan marginalisasi (marginalization) itu sendiri (Rogers, 2010). Dalam membicarakan otonomi wanita, lebih ditekankan pada bagaimanakah peranan seorang wanita di dalam kehidupan rumah tangga, keluarga, dan masyarakatnya. Termasuk diantaranya adalah bagaimana peran wanita yang bekerja, peran wanita dalam mengelola keuangan, peranan wanita dalam konteks hubungan suami istri, dalam konteks mengambil keputusan dan dalam konteks kebebasan bergerak dan berpikir di dalam lingkungan keluarga, rumah tangga, dan masyarakatnya. Pada kenyataan lainnya, didapatkan suatu fenomena dimana wanita dari golongan lapisan bawah terhadap pertanyaan "apakah mereka akan berhenti bekerja kalau suaminya melarang", mereka menjawab bahwa tidak ada pilihan untuk tidak bekerja karena penghasilan mereka mutlak untuk kehidupan rumah tangganya (Ihromi, 2008), sehingga dapat dikatakan bahwa untuk lapisan bawah umumnya wanita bekerja tanpa dipertanyakan apakah hal itu serasi peranannya sebagai ibu rumah tangga. Tetapi disamping bekerja, mereka tetap bertanggung jawab atas pengurusan rumah tangga. Leacock (2009) mengemukakan bahwa kedudukan wanita sangat erat kaitannya dengan sumbangan pada kehidupan ekonomi. Pada masyarakat golongan bawah para wanitanya mempunyai otonomi berkenaan dengan tindakan-tindakan di bidang kerjanya, 
namun mereka tetap juga mempunyai kewajiban untuk melakukan tindakantindakan pengurusan rumah tangga. Dengan kata lain, peranan yang menentukan peranan bukan saja bersifat ekonomi, tetapi peranan-peranan lain juga sangat penting sifatnya dan ikut mempengaruhi kedudukannya. Namun para wanita tetap harus "tahu diri" dalam arti harus sadar mengenai batas-batasnya dan tidak akan bertindak seolah-olah tidak ada ketergantungan dengan suaminya (Van Bemellen, 1995).

\section{Tujuan Dan Manfaat Penelitian}

$\mathrm{P}$ enelitian ini bertujuan untuk mendeskripsikan keseharian isteriisteri nelayan dilihat dari pola nafkah dalam ranah sistem sosial masyarakat dan ekonomi rumah tangga di nagari Tiku Selatan, Kecamatan Tanjung Mutiara, Kabupaten Agam. dapat :

Melalui penelitian ini diharapkan

1. Memberikan solusi terhadap pola pemberdayaan kepada para wanita nelayan sehingga mampu meningkatkan tingkat kesejahteraan rumah tangga nelayan.

2. Melalui hasil kajian ini, diharapkan dapat menemukan model pemberdayaan wanita nelayan untuk peningkatan partisipasi mereka dalam gerak pembangunan, terutama di wilayah pesisir.

3. Hasil penelitian sangat penting dilakukan sehingga menambah kepada bahan-bahan kajian ilmu Sosial, khususnya ilmu Antropologi.

\section{E. Metode Penelitian}

$\mathrm{L}$ okasi penelitian adalah di Nagari Tiku Selatan, Kecamatan Tanjung Mutiara, Kabupaten Agam. Lokasi ini dipilih karena sekitar $60 \%$ masyarakat berlokasi di wilayah pesisir pantai Kecamatan Tanjung Mutiara, dengan persentase sekitar 25\% berprofesi sebagai nelayan. Berdasarkan hasil observasi di lapangan diketahui bahwa berbagai kegiatan produktif yang dilakukan oleh para isteri nelayan untuk menambah pendapatan keluarga/rumah tangga, yaitu menjadi buruh tani, membersihkan kerang, pengupas udang, pedagang keliling, berdagang pakaian bekas dan membuka usaha warung makanan kecil. Usaha lainnya yang dikembangkan adalah membuat kerupuk udang dan kerupuk ikan.

Dalam penelitian ini menggunakan pendekatan penelitian kualitatif. Dalam penelitian kualitatif yang menjadi sasaran kajian adalah kehidupan sosial atau masyarakat sebagai satu kesatuan atau sebuah kesatuan yang menyeluruh. Karena itu, penelitian kualitatif juga biasanya dikaitkan dengan pengertian yang sama dengan pendekatan yang dikenal dalam antropologi yang dinamakan pendekatan holistik. Dalam penelitian kualitatif tidak dikenal sampel tetapi penelitian kasus yang ditelitinya secara mendalam dan menyeluruh untuk memperoleh gambaran mengenai prinsip-prinsip umum atau pola-pola yang berlaku umum berkenaan dengan gejalagejala yang ada dalam kehidupan sosial (Rudito, 2008:79).

Teknik pengumpulan data yang telah dilakukan adalah menggunakan teknik observasi partisipasi, wawancara bebas dan mendalam dan studi kepustakaan. Pemilihan informan diambil secara purposive (sengaja), dimana pengambilan informan yang bersifat tidak acak dan juga berdasarkan pertimbangan-pertimbangan tertentu yang dapat memberikan informasi sesuai dengan masalah yang diteliti. Informan yang telah dipilih adalah isteri-isteri nelayan yang memiliki peran ganda dalam mencari nafkah.

Data-data yang telah dikumpulkan oleh peneliti termasuk juga catatan lapangan dikelompokkan oleh peneliti atas dasar aktivitas khusus yang ada dan diteliti. Kemudian dari pengelompokkan data tersebut, data-data itu kemudian diabstraksikan dan dikaitkan satu dengan lainnya sebagai satu kesatuan kejadian dan fakta yang terintegrasi. Dari abstraksi tersebut maka akan tampak pranata sosial yang berlaku di wilayah atau komuniti tersebut (Bungin, 2004:60). Dalam menganalisis tentunya selalu terkait dengan konsep yang telah dipelajari sebelumnya. Sehingga dari hasil analisis akan tampak kesesuaian dari data yang diperolehnya dengan konsep yang dipelajarinya atau akan berbeda dengan konsep yang dipelajarinya karena masalah sosial akan selalu berbeda antara satu masyarakat dengan masyarakat lainnya. Setelah itu disusun sesuai dengan kategori-kategori dan kemudian disimpulkan. Apabila dalam 
kesimpulan masih menimbulkan keraguan maka dilakukan pengkategorian ulang hingga seluruh data yang telah berhasil dikumpulkan dianggap sesuai dengan tujuan penelitian. Temuan di lapangan akan diolah dengan data yang didapat dari literatur dan akan disajikan dalam suatu karya etnografi deskriptif.

\section{F. Hasil Dan Pembahasan}

1. Gambaran Umum Nagari Tiku Selatan

$\mathrm{N}$ agari $^{1}$ Tiku Selatan terletak di Kecamatan Tanjung Mutiara, Kabupaten Agam, Sumatera Barat. Nagari Tiku Selatan terdiri dari 7 jorong ${ }^{2}$, yang terdiri: (1) Jorong Gasan Kaciak dengan luas wilayah $1.141 \mathrm{Ha}$; (2) Jorong Banda Gadang dengan luas wilayah 724 Ha; (3) Jorong Pasa Tiku dengan luas wilayah $111 \mathrm{Ha}$; (4) Jorong Pasia Tiku dengan luas wilayah $100 \mathrm{Ha}$; (5) Jorong Kampung Darek dengan luas wilayah 520 Ha; (6) Jorong Pasia Paneh dengan luas wilayah $605 \mathrm{Ha}$; dan (7) Jorong Sungai Nibuang dengan luas wilayah $385 \mathrm{Ha}$.

Jumlah jorong yang berada di daerah pesisir sebanyak 4 buah $(21 \%)$ dan jorong bukan pesisir sebanyak 15 buah (79\%), dengan jumlah penduduk pesisir dengan mata pencaharian sebagai nelayan sebanyak 2.152 KK (2\%). Nagari Tiku Selatan berbatasan sebelah utara dengan Nagari Tiku V Jorong, sebelah Selatan dengan Nagari Batang Gasan, sebelah Barat berbatasan dengan Samudra Indonesia dan sebelah Timur berbatasan dengan Nagari Tiku Utara.

Nagari Tiku Selatan memiliki ketinggian tempat berkisar $2 \mathrm{~m}$ dari permukaan laut dengan suhu rata-rata sekitar $26^{\circ} \mathrm{C}-30^{\circ} \mathrm{C}$ dengan rata-rata curah hujan $2000 \mathrm{~mm}$. Wilayah ini terdiri dari

\footnotetext{
${ }^{1}$ Nagari sendiri berasal dari bahasa Sansekerta, dalam bahasa Indonesia berarti kota (ibu kota), istana dan negara atau kerajaan sehingga Minangkabau nagari sering disebut dengan "republik kecil". Nagari adalah pembagian wilayah administratif di propinsi Sumatera Barat di bawah kecamatan yang dipimpin oleh seorang wali nagari.

2 Jorong adalah satu kesatuan di dalam masyarakat yang tinggal di suatu daerah tertentu. Setiap jorong memiliki pemimpin yang disebut wali Jorong yang berada di bawah pemerintahan nagari.
}

dataran rendah, dengan tinggi pesisir pantai yang rendah. Berdasarkan penggunaan lahan dan luas wilayah tersebut bahwa lahan perumahan dan lahan persawahan yang memiliki aliran irigasi mendominasi luas wilayah di Nagari Tiku Selatan, Kecamatan Tiku Selatan, Kabupaten Agam. Nagari Tiku Selatan memiliki garis pantai yang cukup panjang dan juga memiliki keindahan dari aspek pemandangan lautnya.

Berdasarkan data kependudukan Nagari Tiku Selatan tahun 2012, jumlah penduduk sebanyak 13.003 jiwa orang, dengan penduduk laki-laki berjumlah 6.699 jiwa dan penduduk perempuan 6.304 jiwa orang. Jumlah kepala keluarga (KK) adalah 2.608. Berdasarkan hasil wawancara diperoleh bahwa jumlah penduduk terbanyak di Nagari Tiku Selatan yang dikategorikan pada usia produktif berada pada tingkat umur antara 20 tahun hingga 50 tahun. Hal tersebut terkait erat dengan berbagai pekerjaan yang ditekuni oleh masyarakat di Nagari Tiku Selatan.

Dalam pemenuhan kebutuhan hidup masyarakat di Nagari Tiku Selatan, baik kebutuhan dasar seperti kebutuhan sandang, pangan dan papan maupun kebutuhan sekunder seperti kebutuhan pendukung lainnya sangat diperlukan mata pencaharian untuk mencapai usaha tersebut. Dalam pemenuhan kebutuhan tersebut, di dalam masyarakat mempunyai mata pencaharian yang beragam/bervariasi. Demikian juga dengan masyarakat Nagari Tiku Selatan yang memiliki beragam mata pencaharian. Berdasarkan hal tersebut menunjukkan bahwa sebagian besar penduduk di Nagari Tiku Selatan bermata pencaharian sebagai petani, buruh dan nelayan, terutama nelayan buruh sebanyak $145(11 \%)$. Salah satu penyebabnya adalah kondisi wilayah Nagari Tiku Selatan yang terletak memanjang di garis pantai daerah Nagari Tiku Selatan.

Pendidikan merupakan kebutuhan utama masyarakat di Nagari Tiku Selatan sebagai usaha untuk menambah ilmu pengetahuan mereka dan juga mengangkat pada derajat yang lebih tinggi. Kesadaran masyarakat di Nagari Tiku Selatan terhadap pentingnya pendidikan cukup tinggi dimana sebagian besar masyarakatnya sudah mengenyam pendidikan padan tingkat SMP dan SMA. Meskipun demikian, sebagian masyarakatnya juga ada yang menamatkan pendidikan hanya pada tingkat SD. Bahwa 
tingkat pendidikan di Nagari Tiku Selatan sudah cukup tinggi. Hal tersebut diperlihatkan melalui jumlah penduduk yang telah menamatkan pendidikan SD, SMP, SMA dan perguruan tinggi sebanyak 6.350 (90\%). Meskipun demikian, diperoleh juga terdapat penduduk yang tidak menamatkan pendidikan SD (10\%). Pada umumnya, mereka yang tidak menamatkan pendidikan SD dikarenakan faktor ekonomi dan kesempatan.

Untuk menunjang aktivitas pendidikan masyarakat di Nagari Tiku Selatan sangat dibutuhkan sarana dan prasarana agar tujuan pendidikan dapat tercapai. Berdasarkan jumlah sarana pendidikan di Nagari Tiku Selatan cukup memadai dengan tersedianya sarana pendidikan SMP dan SMA. Hal tersebut diperlihatkan dari tingkat pendidikan yang cukup tinggi dengan tingkat pendidikan SMP dan SMA.

\section{Pola Pemukiman Nagari Tiku Selatan}

$\mathrm{P}$ ola pemukiman adalah wujud dari bentuk pemukiman pada suatu daerah yang meliputi pola letak tempat tinggan dan bentuk rumah di pemukiman tersebut. Pola letak pemukiman di Nagari Tiku Selatan tidak berbeda jauh dengan pola pemukiman wilayah pesisir di daerah lain, dimana rumah-rumah membentang sepanjang pantai di pesisir pantai Tiku.

Pola pemukiman Nagari Tiku Selatan yang mengikuti garis pantai dimulai dari Jorong Gasan Kaciak , kemudian dilanjutkan menuju Jorong Banda Gadang, Jorong Pasa Tiku dan Jorong Pasia Tiku. Untuk 3 jorong lainnya berada di sepanjang perbukitan yang berada di seberang garis pantai. Untuk menuju Nagari Tiku Selatan, dapat ditempuh dengan kendaraan beroda dua dan empat dengan sarana jalan yang cukup baik sehingga dapat ditempuh selama 1.5 jam perjalanan dari ibu kota Sumatera Barat, yaitu kota Padang.

Kepemilikan rumah yang berada di sekitar pantai adalah sebagian besar dimiliki oleh rumah tangga nelayan buruh dan juga pedagang ikan berskala kecil. Pada umumnya, bentuk rumah di Nagari Tiku Selatan, terutama kampung-kampung di sekitar pantai terdiri dari rumah tidak permanen dan semi permanen dan hanya beberapa rumah saja yang permanen, yaitu sekitar 5-10 rumah. Untuk rumah-rumah yang berada di sekitar jalan utama yang menghubungkan antar jorong di Nagari Tiku Selatan, keadaannya lebih baik dari rumah yang ada di dekat pantai. Biasanya rumahrumah di wilayah ini dihuni oleh pedagang ikan dengan skala yang lebih besar dibandingkan dengan pedagang yang ada di pinggir pantai.

Berdasarkan observasi (melalui pengamatan), terdapat beberapa rumah di pemukiman sekitar wilayah pantai (5-10 rumah) yang dihuni oleh para nelayan yang tidak layak untuk menjadi tempat tinggal. Rumah mereka hanya beralaskan pasir pantai dan berdindingkan kayu dan juga atapnya terbuat dari seng yang sudah berkarat dan berlubang.

Di sekitar pemukiman nelayan, terdapat 2-4 warung makanan yang selalu dipenuhi oleh para nelayan buruh, terutama sekali ketika mereka sudah selesai melaksanakan aktivitas penangkapan ikan seperti memukat dan juga pada saat terjadinya badai (cuaca tidak baik). Aktivitas yang biasa mereka lakukan adalah berdiskusi tentang aktivitas penangkapan ikan, bermain domino/kartu dan hanya sekedar minum kopi.

\section{Aktivitas Sosial Budaya Masyarakat}

$\mathrm{M}$ asyarakat menganut matrilineal,

nagari Tiku Selatan sistem kekerabatan yakni kekerabatan mengacu kepada garis keturunan perempuan. Tradisi sosial yang paling unik di nagari ini adalah tradisi perkawinan dan kematian. Tradisi perkawinan adalah perempuan 'membeli' laki-laki, artinya perempuan yang membayar biaya dan mahar perkawinan. Dalam tradisi ini ada konsep uang 'hilang' dan uang 'menjemput'. Uang hilang adalah uang yang digunakan untuk mengganti pengeluaran orangtuanya dalam membesarkan anak laki-lakinya baik berupa uang atau barang seperti motor atau mobil. Penggantian uang hilang ini tergantung kepada tingkat pendidikan dan pekerjaan laki-laki tersebut, apabila tinggi pendidikannya maka semakin tinggi uang hilangnya. Untuk uang menjemput adalah uang yang dibayar ketika menjemput lakilaki saat pelaksanaan pernikahan, dengan uang menjemput berupa ringgit sebanyak 12 emas. Dalam tradisi perkawinan ini didalamnya terdapat prosesi seperti adat menurunkan pengantin perempuan dari 
rumah ibunya (bundo kanduang), adanya upacara mencukur rambut, 'balatui badia', adat menjemput pengantin laki-laki (bagalombang duo baleh).

Selain tradisi perkawinan, tradisi kematian di wilayah ini terbilang unik. Tradisi kematian disebut dengan istilah 'batagak adat' dengan cara 'Bejamba', yaitu masingmasing keluarga, tetangga dan kerabat dalam satu suku yang melayat membawa makanan yang kemudian ditumpuk-tumpuk menjadi sebuah gunung makanan hingga mencapai lebih kurang 2 meter. Setelah makanan menggunung, maka dilaksanakan acara berdoa (zikir) bersama, setelah itu dilakukan kegiatan membagi-bagi harta warisan, "malewang gala", upacara doa setelah 3, 7, 14, 40 dan 100 hari kematian anggota keluarga.

\section{Aktivitas Ekonomi Perikanan Masyarakat}

ktivitas ekonomi perikanan yang
dilakukan oleh nelayan pada
umumnya dilakukan berkelompok tetapi ada juga yang melakukannya secara perorangan. Kegiatan tersebut sebagian besar dilakukan oleh pihak laki-laki yang berumur diatas 15 tahun. Pendapatan nelayan di nagari Tiku Selatan berkisar antara Rp.25.000,- hingga Rp. 100.000,-. Pendapatan nelayan termasuk rendah dikarenakan sebagian besar nelayan di nagari Tiku Selatan tersebut adalah nelayan buruh (60\%). Aktivitas penangkapan ikan pada masyarakat nelayan Nagari Tiku Selatan, yaitu aktivitas membagan, memayang, memukat dan menjaring. Teknologi pada penangkapan ikan menjaring menggunakan peralatan jaring dan perahu. Jaring yang selalu dipergunakan oleh masyarakat nelayan Nagari Tiku Selatan adalah yang berukuran 100-200 m. Jaring ini ada yang jahitannya halus dan kasar. Jaring yang halus ukuran matanya memiliki panjang $25-20 \mathrm{~cm}$ dan lebarnya kira-kira $5 \mathrm{~cm}$, sedangkan jaring yang jahitannya kasar ukuran matanya memiliki panjang 50-60 $\mathrm{cm}$ dan lebar $10 \mathrm{~cm}$. Untuk jahitan yang kasar adalah untuk menangkap ikan yang besar-besar seperti ikan gembolo, ikan gurigak, belatuk dan soaso, sedangkan jahitan yang halus atau rapat adalah untuk menangkap ikan yang kecil-kecil seperti ikan campu, pinangpinang, maco dan tete. Untuk menangkap ikan dengan menjaring mempergunakan sebuah perahu yang panjangnya lebih kurang $4 \mathrm{~m}$ dan lebarnya $1 \mathrm{~m}$. Perahu yang banyak digunakan oleh masyarakat nelayan Nagari Tiku Selatan saat ini sudah banyak memakai mesin perahu/mesin tempel.

Hasil tangkapan ikan yang diperoleh langsung di bawa ke pasar tradisional Tiku Selatan dan disana sudah ada agen atau pembeli yang menanti. Biasanya agen-agen tersebut telah ditentukan oleh induk semang. Alasan lain nelayan menjual ikan di pasar tradisional Tiku Selatan karena semua jenis ikan dapat diterima baik besar maupun kecil, begitu juga dengan jenis-jenisnya.

Nagari Tiku Selatan merupakan Nagari yang memiliki potensi sumber daya alam yang cukup banyak dilihat dari berbagai aspek seperti Nagari Tiku Selatan mempunyai wilayah laut yang dengan garis pantai sepanjang $\pm 6 \mathrm{~km}$ dan disertai dengan Tempat Pendaratan Ikan (TPI) beserta fasilitas penunjang lainnya. Potensi hasil laut nagari Tiku Selatan telah menjadi salah satu andalan ekonomi yang utama dari nagari Tiku Selatan.

Dari segi infrastruktur dan perhubungan Nagari Tiku Selatan dilalui oleh jalan negara yang menghubungkan Ibukota Propinsi dan lbukota Kabupaten. Ditambah dengan beradanya ibukota Kecamatan Tanjung Mutiara di Nagari Tiku Selatan, maka hampir seluruh kantor instansi pemerintah dan swasta serta sekolah-sekolah berada di Nagari Tiku Selatan. Dari Segi Ekonomi otomatis dengan keberadaan TPI dan pasar serikat , maka seluruh aktifitas utama perikanan dan ekonomi berada di Nagari Tiku Selatan . Ditambah dengan keberadaan kantor beberapa Bank BPR dan bank umum, Koppem serta BMT yang terletak di Nagari Tiku Selatan yang sangat membantu pertumbuhan ekonomi masyarakat. Dari segi sumber daya manusia Nagari Tiku Selatan mempunyai asset SDM yang cukup banyak dengan tingkat pendidikan yang cukup tinggi serta mempunyai beragam keahlian. Namun potensi tersebut belum tergali dan dimanfaatkan secara maksimal.

\section{Gambaran Pekerjaan Isteri-Isteri Nelayan}

$\mathrm{K}$ egiatan perempuan, utamanya isteri, di Nagari Tiku Selatan khususnya di Jorong Pasie Tiku, dalam bidang ekonomi banyak terkonsentrasi pada sektor informal. Mereka memiliki cara-cara atau 
terobosan-terobosan yang sangat berarti dalam membantu suami untuk menunjang kelangsungan ekonomi rumah tangga mereka. Istri juga dituntut untuk ikut berperan dalam mencari tambahan penghasilan untuk memenuhi kebutuhan keluarga, sehingga mereka tidak hanya tinggal diam di rumah untuk menanti dan membelanjakan penghasilan suami mereka dari melaut, namun mereka juga ikut terlibat dalam kegiatan mencari nafkah.

Peran perempuan dalam nafkah rumah tangga dimulai ketika perahu mulai kembali dari melaut dan membawa hasil tangkapan. Pada saat itu, perempuan terlibat dalam penjualan hasil tangkapan. Di Nagari Tiku Selatan khususnya di Jorong Pasie Tiku, perempuan mempunyai peran yang berarti hingga terjualnya hasil tangkapan. Sebagian besar perempuan ini adalah istri dari nelayan yang melaut. Mereka mempunyai tanggung jawab untuk menjual hasil tangkapan di pasar maupun di Tempat Pendaratan Ikan (TPI).

Pada waktu pendaratan, para perempuan yang sebagaian besar adalah istri nelayan akan menunggu perahu suaminya mendarat di tempat pendaratan. Mereka secara bersama-sama akan membantu suami mereka untuk menurunkan hasil tangkapan kemudian membawanya ke tempat penjualan, sedangkan kaum laki-laki beristirahat untuk melepas lelah di warungwarung sekitar tempat pendaratan atau langsung pulang ke rumah.

Penjualan ikan ini dikoordinasi oleh istri pemilik perahu atau oleh orang kepercayaan pemilik perahu. Hasil tangkapan ini dijual pada pedagang. Pedagang yang dikenal dengan istilah toke ini sebagian besar adalah penduduknya sendiri. Mereka berjualan ikan, baik di pasar Tiku maupun pasar nagari lainnya, bahkan ada yang berjualan hingga pasar kabupaten. Peran perempuan dalam pemasaran hasil tangkapan tidak memberikan kontribusi pendapatan secara langsung dalam nafkah rumah tangga. Di sini, mereka hanya berperan membantu memasarkan hasil tangkapan dan tidak mengambil keuntungan dari kegiatan tersebut, seluruh hasil penjualan diserahkan pada istri pemilik perahu untuk kemudian dibagi sesuai dengan peran masing-masing dalam penangkapan ikan. Pemilik perahu mendapatkan bagian sebanyak $60 \%$ sedangkan sisanya dibagi rata kepada seluruh awak perahu. Suatu hal yang berbeda jika perempuan berperan sebagai pedagang ikan. Sebagai pedagang, mereka mendapatkan keuntungan dari selisih harga penjualan dan pembelian. Rata-rata pendapatan yang diterima oleh pedagang ikan berkisar antara Rp. 10.000,00 hingga Rp. 50.000,00 setiap harinya. Besarnya pendapatan ini sangat tergantung pada besarnya modal yang mereka kelola. Semakin besar modal yang dimiliki, mereka dapat membeli ikan dalam jumlah banyak dan memasarkannya hingga ke pasar desa lain atau bahkan pasar kabupaten.

Di Nagari Tiku Selatan khususnya di Jorong Pasie Tiku, selain dijual langsung ke konsumen dalam bentuk segar, beberapa bakul merangkap sebagai pembuat pindang. Pindang adalah salah satu bentuk pengolahan sekaligus pengawetan ikan dengan cara memasak ikan pada suatu tungku yang terbuat dari tanah liat. Pemindangan dilakukan sebagai upaya meningkatkan nilai jual ikan dan juga menjaga keawetan ikan, sehingga mengurangi risiko kerugian apabila ikan tidak segera laku terjual. Hasil pemindangan kemudian dijual kepada beberapa pedagang, baik yang berjualan di pasar maupun pedagang keliling. Nagari Tiku Selatan khususnya di Jorong Pasie Tiku, kegiatan produktif perempuan nelayan yang lain adalah sebagai pembuat pembuat jajanan rakik maco sejenis keripik pedas gurih dari tepung beras yang dibubuhi ikan laut kecil dan tipis dibagian atasnya (toping). Rata-rata dalam sehari, mereka dapat membuat jajanan sebanyak $5-10 \mathrm{~kg}$. Pekerjaan ini dapat diselesaikan dalam waktu kurang dari setengah hari.

Di Jorong Pasie Tiku, juga dijumpai kegiatan pengasinan ikan. Beberapa jenis ikan yang mempunyai nilai ekonomi rendah diolah menjadi ikan asin. Tujuan kegiatan ini adalah untuk mengawetkan ikan dan juga meningkatkan nilai ekonominya. Ikan segar dibersihkan kemudian dibelah, dilumuri garam, dan dijemur di bawah sinar matahari. Sepanjang jalan, banyak dijumpai papan kayu memanjang tempat penjemuran ikan. Selain istri, kegiatan ini seringkali melibatkan anak perempuan, utamanya untuk membantu menunggu dagangan ikan di pasar atau mengolah ikan untuk dibuat pindang.

Anak-anak perempuan ini mengisi waktu luangnya setelah pulang sekolah dengan bermain dan membantu orangtua mereka. Pada perempuan yang telah 
menginjak remaja, tanggung jawab yang diberikan oleh orang tua menjadi semakin besar. Mereka membantu menyelesaikan pekerjaan rumah sehari-hari seperti memasak, berbelanja, membersihkan rumah, mencuci pakaian, hingga mengasuh adik. Selain itu, mereka juga terlibat dalam kegiatan produktif seperti membersihkan ikan, mengupas udang, atau sekedar menunggu dagangan di pasar. Munculnya usaha kecil di pedesaan membawa dampak pada semakin meningkatnya peran perempuan dalam nafkah rumah tangga. Sumbangan perempuan dalam nafkah rumah tangga mengalami peningkatan. Kegiatan perempuan tidak lagi terbatas pada kegiatan pemasaran hasil tangkapan, namun lebih jauh dari itu, mereka terlibat dalam pekerjaan pengolahan.

Pada masyarakat di jorong Pasie Tlku, bukan hal baru apabila perempuan (istri) terlibat dalam nafkah rumah tangganya. Keterlibatan istri dalam nafkah rumah tangg mendapat dukungan dari para suami, sebab disamping pekerjaan ini tidak mengganggu tugas ibu sebagai ibu rumah tangga, juga sebagai upaya istri untuk mendapatkan nafkah tambahan guna memenuhi kebutuhan hidup sehari-hari. Kajian tentang peran perempuan dalam nafkah rumah tangga, utamanya di pedesaan menunjukkan bahwa peranan perempuan dalam sistem nafkah rumah tangga cukup signifikan. Kondisi ini menunjukkan bahwa peranan perempuan sebagai pelaku ekonomi tidak boleh diabaikan, bahkan diperlukan dukungan teknologi untuk menunjang peranan perempuan dalam kegiatan sosial dan ekonomi agar para perempuan dapat mengalokasikan waktunya lebih banyak pada kegiatan produktif tanpa meninggalkan peranannya pada kegiatan domestik. Berbagai studi di negara berkembang telah menunjukkan bahwa peran perempuan dalam ekonomi rumah tangga sangatlah besar. Bahwa perempuan mempunyai peran dalam aktivitas ekonomi rumah tangga. Pada usaha tani, perempuan memberikan sumbangan curahan waktu kerja yang hampir sama dengan laki-laki. Kontribusi dalam aspek aktivitas ekonomi ini tidak diimbangi dengan peran pada aspek kontrol atau pengambilan keputusan. Pengambilan keputusan dalam rumah tangga masih didominasi oleh laki-laki (suami).

Peran perempuan pedesaan relatif lebih tinggi dalam kegiatan pascapanen dan kegiatan pengelolaan ternak daripada kegiatan pertanian lainnya. Partisipasi mereka hampir nihil dalam hal kegiatan budidaya, sedangkan beberapa dari mereka berpartisipasi dalam kegiatan non-pertanian seperti pembuatan kerajinan tangan dan menjahit. Penelitian ini juga menunjukkan bahwa perempuan pada rumah tangga petani memberikan kontribusi pendapatan rumah tangga melalui berbagai aktivitas ekonomi. Temuan lainnya menunjukkan bahwa di sebagian besar kasus partisipasi perempuan dalam proses pengambilan keputusan mengenai berbagai urusan rumah tangga lebih rendah daripada lakilaki.

Peningkatan peran perempuan lebih disebabkan oleh kondisi sosial ekonomi rumah tangga. Kebutuhan rumah tangga menjadi salah satu faktor utama yang menyebabkan perempuan bekerja di luar rumah. Walaupun di sebagian besar negara berkembang, perempuan diposisikan lebih inferior dibandingkan laki-laki, namun pergeseran peran yang terjadi merupakan suatu kebutuhan. Nilai-nilai budaya yang ada di masyarakat, mau tidak mau, harus bisa berkompromi dengan peningkatan kebutuhan rumah tangga.

\section{Karakteristik Informan \\ a. Informan 1:}

Informan ini bernama Wati, berumur 47 tahun dan telah memiliki 5 orang anak. Yang sulung telah menikah dan tinggal di daerah lain, 4 anak lainnya masih tinggal dirumah bersama informan. Informan menempati rumah semi permanen berjarak 50-an meter dari bibir pantai Tiku berukuran lebih kurang $6 \times 9$ yang dibangun tahun 2010 setelah bencana gempa.

Dahulu suami informan bekerja sebagai nelayan, namun karena kondisi kesehatan yang tidak memungkinkan lalu berhenti ikut melaut. Saat ini suami informan bekerja sebagai karyawan pabrik batu es, namun 3 bulan terakhir menderita sakit gula dan sering tidak dapat pergi bekerja. Namun menurut informan gaji suaminya yang berjumlah 1 juta perbulan masih dibayarkan oleh pabrik. Informan mengaku penghasilan suami bekerja sebagai karyawan pabrik es masih belum mencukupi, namun menurutnya jauh lebih baik dari pada mengandalkan hasil melaut yang seringkali tidak menentu bahkan terkadang sama sekali tidak membawa hasil. Dengan keadaan suami informan yang sakit saat ini, 
informan cemas sewaktu-waktu pabrik akan berhenti membayar gaji suaminya. Bekerja sebagai guru mengaji dengan gaji 40.000 rupiah / minggu (160.000/bulan). Membuat kue donat untuk dijual di mesjid tempat dia mengajar dengan pendapatan bersih ratarata 20.000/hari $\times 6$ hari $\times 4$ minggu $=$ 480.000 / bulan. Total perkiraan rata-rata penghasilan informan $=640.000 /$ bulan. Ada kalanya informan membantu pengolahan (pengeringan atau perebusan) hasil tangkapan ikan nelayan dengan upah yang tak tentu tergantung jumlah tangkapan berkisar 20.000/hari dengan total rata-rata hari kerja 6 hari /bulan. Total pendapatan = $120.000 /$ bulan.

Sebagai pengajar dan penyanyi grup rebana qasidahan dengan rata-rata 3 kali penampilan / bulan dengan upah ratarata 30.000 / 1 kali tampil. Total 90.000 / bulan. Total rata-rata pendapatan RT informan setelah ditambah dengan gaji suami 1.850.000/bulan. Informan memperkirakan belanja RT nya sehari-hari berkisar 75.000/ hari. Total pengeluaran dalam 1 bulan = 2.250.000 / bulan. (belum dapat informasi tentang bagaimana informan persisnya menutup kekurangan pendapatan dibandingkan besarnya pengeluaran). Bangun jam 5 pagi, informan memulai hari dengan menggoreng kue donat yang telah di adon sejak tadi malam sembari mengerjakan pekerjaan rt lainnya seperti menyapu dan membersihkan rumah, merendam cucian, membangunkan anakanak yang akan berangkat sekolah. Jam 7 pagi informan telah selesai menggoreng donat lalu mengantarkannya ke sekolah yang berjarak 300-an meter dari rumah. Setiap hari informan membuat lebih kurang 50 buah kue donat dengan harga jual $\mathrm{Rp}$ 500/buah (informan hanya memperoleh $\mathrm{Rp}$ 400/donat, dan penjual Rp 100/donat)

Menjelang siang hari, informan sudah disibukkan dengan kegiatan memasak di dapur dan menyelesaikan pekerjaan mencuci pakaian. Siang hari terkadang diisi oleh informan melatih grup rebana jorong setempat. Selain melatih memainkan rebana, informan juga adalah penyanyi grup rebana yang mendapat bayaran sekitar 30.000 setiap kali tampil. Sore hari menjelang waktu sholat Ashar, informan berangkat ke musholla untuk sholat Ashar berjamaah dan dilanjutkan dengan mengajar mengaji anak-anak setelah ashar hingga menjelang jam 6 sore. Malam hari setelah sholat Isya, informan menyiapkan adonat donat untuk digoreng esok pagi.

\section{b. Informan 2}

Informan ini bernama Ida (50 tahun), telah menikah dan memiliki 9 orang anak, 1 diantaranya tinggal di Medan bersama kakak suami Informan sedang 8 lainnya tinggal bersama dirinya. Anak sulungnya baru saja tamat SMA, 2 yang lainnya masih SMA/SMK dan kost di ibu kota kabupaten yang berjarak setengah jam perjalanan, kemudian berturut-turut SMP 2 orang dan SD 3 orang serta 2 terkecil belum sekolah sedangkan yang terkecil usianya 1 tahun 8 bulan. Jadi total anggota rt informan adalah 11 orang: 8 anak+ informan suami istri dan ibu informan yang tinggal seorang diri. Rumah informan yang bersebelahan dengan rumah ibunya, berukuran $6 \times 8$ meter semi permanen dan berjarak lebih kurang 100 meter saja dari bibir pantai.

Suami informan bekerja sebagai nelayan dan saat diwawancarai tengah pergi melaut sejak seminggu yang lalu. Informan menjelaskan bahwa ia tidak dapat mengandalkan pekerjaan suaminya sebagai nelayan. Jika ada, ia hanya mendapatkan Rp 50.000,- / hari dari suami. Seringkali hasilnya hanya sekedar belanja pribadi suaminya saja bahkan menurut informan tidak jarang pula suami pulang tidak membawa hasil sama sekali, sehingga informan yang harus memberi uang pada suami untuk kebutuhan membeli rokok dan minum di warung.

Anak laki-laki sulung informan yang telah tamat SMA saat ini bekerja sebagai nelayan kapal bagan ikan. Saat wawancara ini berlangsung, anak informan tersebut telah 10 hari melaut dengan wilayah jelajah hingga kepulauan Mentawai. Dari anak sulungnya tersebut, informan terkadang mendapat uang hingga Rp 200.000 setiap kali pulang melaut. Tapi tidak jarang pula ia tidak memberi ibunya uang disebabkan minimnya hasil tangkapan laut. Pada saat seperti ini, informanlah yang justru memberi anaknya uang. Informan sehari-hari bekerja sebagai pembuat jajanan rakik maco sejenis keripik pedas gurih dari tepung beras yang dibubuhi ikan laut kecil dan tipis dibagian atasnya (toping). Setiap hari informan membuat sampai 500 rakik maco yang dijual perbuahnya Rp 500,-

Pada hari-hari tertentu (rabu dan kamis) informan juga membuat palai bada (pepes ikan) atau sate lokan (sate kerang) 
untuk di jajakan bersamaan dengan rakik maco._Informan menjelaskan bahwa ratarata keuntungan yang dapat diperoleh dari berdagang jajanan khas tersebut berkisar Rp 50.000 - Rp 150.000/hari._Perkiraan hasil pendapatan RT informan sehari: hasil berjualan $\mathrm{Rp} 100.000$ + Rp 50.000 (dari suami) + Rp 20.000 (dari anak) = Rp $170.000 \times 20$ hari $=R p 3.400 .000 /$ bulan . Perkiraan belanja harian RT informan adalah Rp 200.000 / hari meliputi belanja untuk konsumsi 11orang, belanja keperluan sekolah dan keperluan harian lainnya. Jadi total pengeluaran informan sekeluarga sebulan lebih kurang $\mathrm{Rp} 200.000 \times 30$ hari $=$ Rp 6.000.000,- (dalam wawancara singkat ini, tidak dapat ditelusuri bagaimana persisnya informan dan keluarga menutupi kekurangan ini).

Informan memulai hari jam 5 pagi untuk sholat subuh dan membereskan rumah dan anak-anak yang akan berangkat sekolah sembari informan menata rakik maco ke dalam wadah besar yang bisa memuat hingga 600 keping rakik maco. Jam 9 pagi, informan telah bersiap-siap berangkat menjajakan dagangan ke ibu kota Kabupaten. Wadah besar yang berisi rakik maco di junjung informan diatas kepalanya sambil menjajakannya ke kantor-kantor dinas di kota Lubuk Basung.

Sebelum berangkat iamenitipkan 2 anak terkecil pada ibunya yang tinggal di depan rumah Informan. Sementara untuk makan siang terkadang informan siapkan sebelumnya atau disiapkan oleh ibu dan anak-anaknya yang SMP dan telah bisa mandiri. Informan sampai di rumah kembali sekitar jam 6 sore, beristirahat sebentar sebelum sholat magrib dan kemudian setelah sholat maghrib, informan kembali bekerja menyiapkan adonan rakik untuk di jual esok pagi. Biasanya informan baru selesai menggoreng 500-600 rakik hingga jam 12 malam. Pada hari sabtu dan minggu, informan dapat beristirahat dan mengisi waktunya mengerjakan pekerjaan rumah atau memenuhi berbagai kewajiban sosial atau undangan perhelatan pernikahan dan lain sebagainya.

\section{c. Informan 3}

Informan ini bernama Fatmawati berusia 50 tahun, telah menikah dan memiliki 9 orang anak, 1 diantaranya tinggal di Medan bersama kakak suami Informan sedang 8 lainnya tinggal bersama dirinya. Anak sulungnya baru saja tamat SMA, 2 yang lainnya masih SMA/SMK dan kost di ibu kota kabupaten yang berjarak setengah jam perjalanan, kemudian berturut-turut SMP 2 orang dan SD 3 orang serta 2 terkecil belum sekolah sedangkan yang terkecil usianya 1 tahun 8 bulan. Jadi total anggota rt informan adalah 11 orang: 8 anak+ informan suami istri dan ibu informan yang tinggal seorang diri. Rumah informan yang bersebelahan dengan rumah ibunya, berukuran 6 × 8 meter semi permanen dan berjarak lebih kurang 100 meter saja dari bibir pantai.

Suami informan bekerja sebagai nelayan dan saat diwawancarai tengah pergi melaut sejak seminggu yang lalu. Informan menjelaskan bahwa ia tidak dapat mengandalkan pekerjaan suaminya sebagai nelayan. Jika ada, ia hanya mendapatkan Rp 50.000,- / hari dari suami. Seringkali hasilnya hanya sekedar belanja pribadi suaminya saja bahkan menurut informan tidak jarang pula suami pulang tidak membawa hasil sama sekali, sehingga informan yang harus memberi uang pada suami untuk kebutuhan membeli rokok dan minum di warung.

Anak laki-laki sulung informan yang telah tamat SMA saat ini bekerja sebagai nelayan kapal bagan ikan. Saat wawancara ini berlangsung, anak informan tersebut telah 10 hari melaut dengan wilayah jelajah hingga kepulauan Mentawai. Dari anak sulungnya tersebut, informan terkadang mendapat uang hingga $\mathrm{Rp} 200.000$ setiap kali pulang melaut. Tapi tidak jarang pula ia tidak memberi ibunya uang disebabkan minimnya hasil tangkapan laut. Pada saat seperti ini, informanlah yang justru memberi anaknya uang. Informan sehari-hari bekerja sebagai pembuat jajanan rakik maco sejenis keripik pedas gurih dari tepung beras yang dibubuhi ikan laut kecil dan tipis dibagian atasnya (toping). Setiap hari informan membuat sampai 500 rakik maco yang dijual perbuahnya Rp 500,-

Pada hari-hari tertentu (rabu dan kamis) informan juga membuat palai bada (pepes ikan) atau sate lokan (sate kerang) untuk di jajakan bersamaan dengan rakik maco._Informan menjelaskan bahwa ratarata keuntungan yang dapat diperoleh dari berdagang jajanan khas tersebut berkisar Rp 50.000 - Rp 150.000/hari._Perkiraan hasil pendapatan RT informan sehari: hasil berjualan $\mathrm{Rp} 100.000$ + Rp 50.000 (dari suami) + Rp 20.000 (dari anak) = Rp $170.000 \times 20$ hari $=\operatorname{Rp} 3.400 .000 /$ bulan . 
Perkiraan belanja harian RT informan adalah Rp 200.000 / hari meliputi belanja untuk konsumsi 11orang, belanja keperluan sekolah dan keperluan harian lainnya. Jadi total pengeluaran informan sekeluarga sebulan lebih kurang Rp $200.000 \times 30$ hari $=$ Rp 6.000.000,- (dalam wawancara singkat ini, tidak dapat ditelusuri bagaimana persisnya informan dan keluarga menutupi kekurangan ini).

Informan memulai hari jam 5 pagi untuk sholat subuh dan membereskan rumah dan anak-anak yang akan berangkat sekolah sembari informan menata rakik maco ke dalam wadah besar yang bisa memuat hingga 600 keping rakik maco. Jam 9 pagi, informan telah bersiap-siap berangkat menjajakan dagangan ke ibu kota Kabupaten. Wadah besar yang berisi rakik maco di junjung informan diatas kepalanya sambil menjajakannya ke kantor-kantor dinas di kota Lubuk Basung.

Sebelum berangkat ia menitipkan 2 anak terkecil pada ibunya yang tinggal di depan rumah Informan. Sementara untuk makan siang terkadang informan siapkan sebelumnya atau disiapkan oleh ibu dan anak-anaknya yang SMP dan telah bisa mandiri. Informan sampai di rumah kembali sekitar jam 6 sore, beristirahat sebentar sebelum sholat magrib dan kemudian setelah sholat maghrib, informan kembali bekerja menyiapkan adonan rakik untuk di jual esok pagi. Biasanya informan baru selesai menggoreng 500-600 rakik hingga jam 12 malam. Pada hari sabtu dan minggu, informan dapat beristirahat dan mengisi waktunya mengerjakan pekerjaan rumah atau memenuhi berbagai kewajiban sosial atau undangan perhelatan pernikahan dan lain sebagainya.

\section{Strategi Pola Nafkah Ganda Nelayan}

trategi nafkah yang diterapkan oleh - rumah tangga nelayan di Jorong Pasie Tiku dibedakan menjadi dua macam, yaitu strategi ekonomi (Tabel 1) dan strategi sosial (Tabel 2). Strategi ekonomi yang digunakan berupa pola nafkah ganda, optimalisasi tenaga kerja rumah tangga dan migrasi. Sedangkan strategi sosial berupa pemanfaatan lembaga kesejahteraan lokal dan jejaring sosial seperti kekerabatan, pertetanggaan dan perkawanan. Pemanfaatan tenaga kerja dalam rumah tangga menjadi salah satu strategi ekonomi yang dilakukan oleh rumah tangga miskin. Anggota rumah tangga dilibatkan secara aktif dalam menambah pendapatan rumah tangga.

Anggota rumah tangga berjenis kelamin laki-laki, utamanya mereka yang sudah dewasa, cenderung terlibat dalam kegiatan penangkapan. Sedangkan yang masih anak-anak keterlibatannya terbatas pada memilih ikan hasil tangkapan, menarik perahu hingga memperbaiki jaring. Anggota rumah tangga perempuan terlibat dalam penjualan ikan hasil tangkapan. Strategi nafkah yang dominan dilaksanakan adalah migrasi. Untuk memenuhi kebutuhan hidupnya, banyak anggota rumah tangga nelayan miskin yang melakukan migrasi ke beberapa kota besar. Sebagian besar pelaku migrasi adalah laki-laki dan setelah dirasa sukses mereka akan menetap di kota-kota besar tersebut. Pelaku migrasi pada umumnya masih berusia muda, mereka tidak lagi tertarik dengan pekerjaan sebagai nelayan. Rendahnya pendapatan menjadi salah satu alasan mereka untuk meninggalkan sektor perikanan tangkap yang selama ini digeluti oleh orang tua mereka. Selain itu daya tarik kehidupan kota masih menjadi salah satu faktor pendorong terjadinya migrasi.

Pelaku migrasi pada umumnya masih berusia muda dan bekerja di kota besar pada sektor informal. Tujuan migrasi adalah kota-kota besar yang ada di Jawa Timur. Selain itu, Jakarta merupakan salah satu kota tujuan yang paling diminati. Jenis pekerjaan yang dilakukan antara lain pedagang kaki lima, buruh pabrik, tukang becak hingga pengepul besi tua.

Migrasi dilakukan secara berkelompok baik berdasarkan kekerabatan atau hubungan sosial yang lain. Sudah menjadi kebiasaan apabila ada perantau yang telah sukses akan mengajak kerabat, tetangga dan teman untuk ikut serta merantau. Selama dalam perantauan, kebutuhan hidup akan ditanggung oleh perantau yang telah sukses. Bahkan tak jarang mereka yang telah sukses bersedia untuk memberi pinjaman modal. 
Tabel 1.Strategi Ekonomi Rumah Tangga Nelayan di di Nagari Tiku Selatan

\begin{tabular}{|l|l|l|}
\hline $\begin{array}{l}\text { Strategi Ekonomi } \\
\text { Kegiatan }\end{array}$ & Kegiatan & Pelaku \\
\hline Pola nafkah ganda & $\begin{array}{l}\text { Jasa perbaikan perahu dan } \\
\text { jaring, }\end{array}$ & Laki-laki \\
\hline $\begin{array}{l}\text { Optimalisasi tenaga kerja } \\
\text { rumah tangga }\end{array}$ & $\begin{array}{l}\text { Terlibat dalam penangkapan } \\
\text { ikan, Membantu dalam } \\
\text { perbaikan perahu atau jaring } \\
\text { Membantu menjual hasil } \\
\text { tangkapan, membuat ikan } \\
\text { asin, jajanan rakik macho }\end{array}$ & Laki-laki \\
\hline
\end{tabular}

Sumber: Data Primer, 2013

Peran perempuan juga menjadi salah satu harapan dalam pengembangan strategi nafkah berkelanjutan. Pemanfaatan ikatan sosial antar penduduk perempuan yang selama ini ada perlu untuk ditingkatkan sehingga memberi peluang akses terhadap modal finasial. Dukungan dari penduduk laki-laki (suami atau ayah) sangat menentukan. Kegiatan perempuan selama ini masih terbatas pada kegiatan reproduktif dengan curahan waktu yang cukup tinggi. Sedangkan, kontribusi perempuan dalam pendapatan rumah tangga masih terbatas. Tanpa adanya dukungan dari laki-laki, peningkatan peran perempuan nafkah rumah tangga menjadi terbatas. Bentuk dukungan dapat berupa pemberian informasi dan pemberian fasilitas bagi istri untuk melaksanakan kegiatan produktif seperti arisan, pelatihan, simpan pinjam dan sebagainya. yang ada. Kelembagaan kesejahteraan tradisional juga mempunyai peran yang penting bagi rumah tangga miskin dalam memenuhi kebutuhan hidupnya. Apabila dilihat dari basis nafkah yang dilakukan, rumah tangga miskin melakukan upaya diversifikasi nafkah pada semua sektor baik on farm, off farm maupun non farm. Keterlibatan perempuan di Kwanyar Barat masih terbatas pada kegiatan perikanan tangkap.

Tabel 2. Strategi Sosial Rumah Tangga Nelayan di Nagari Tiku Selatan

\begin{tabular}{|l|l|l|}
\hline \multicolumn{1}{|c|}{ Strategi Ekonomi } & \multicolumn{1}{|c|}{ Kegiatan } & \multicolumn{1}{c|}{ Pelaku } \\
\hline $\begin{array}{l}\text { Pemanfaatan Lembaga } \\
\text { Sosial }\end{array}$ & $\begin{array}{l}\text { Yasinan, Julo-Julo, Arisan, } \\
\text { Takziah }\end{array}$ & Perempuan atau laki-laki \\
\hline Jejaring Sosial & $\begin{array}{l}\text { Hutang pada } \\
\text { kerabat/tetangga } \\
\text { Tukar menukar informasi } \\
\text { pekerjaan }\end{array}$ & Perempuan atau laki-laki \\
\hline
\end{tabular}

Sumber: Data Primer, 2013

Strategi sosial lainnya adalah memanfaatkan ikatan sosial seperti kekerabatan, pertetanggaan maupun pertemanan. Ketika ekonomi berkembang, bentuk hubungan timbal balik ini mengalami perkembangan. Model tukar menukar tenaga kerja berkembang menjadi model kerja sama baik berdasarkan bagi hasil maupun pengupahan. Di Nagari Tiku Selatan, selain berupa tukar menukar tenaga kerja, saling tukar menukar informasi tentang peluang pekerjaan menjadi salah satu bentuk strategi sosial ini. Seringkali informasi maupun ajakan bermigrasi datang dari kerabat, tetangga maupun teman.
Ikatan kekerabatan yang kuat menjadikan rumah tangga miskin dapat bertahan hidup di kota-kota besar. Beberapa diantaranya ada yang hanya bermodalkan nekat untuk berangkat ke kota besar. Selama belum memperoleh pekerjaan atau mempunyai usaha, mereka akan dibantu oleh kerabat yang sudah sukses. Sudah menjadi kewajiban bagi kerabat yang sudah sukses untuk membantu kerabat lainnya.

Di dalam masyarakat sendiri, utang merupakan salah satu penggunaan modal sosial yaitu hubungan sosial yang ada di dalam desa. Rasa saling mempercayai antar warga cukup tinggi 
sehingga proses hutang piutang dapat berlangsung dengan baik. Namun demikian apabila sekali saja terdapat pelanggaran, maka rasa kepercayaan tersebut akan dengan cepat luntur. Rumah tangga miskin sangat berhati-hati dalam menjaga hubungan sosial berbasis kepercayaan ini. Sekali saja mereka berbuat salah atau mengingkari janji, maka seumur hidup akan tidak dipercayai oleh orang lain. Strategi nafkah yang selama ini dijalankan oleh rumah tangga miskin di Nagari Tiku Selatan sangat kental sekali dengan pemanfaatan modal sosial. Akses terhadap modal sosial boleh dibilang sebagai satu-satunya akses terhadap modal. Kekuatan modal sosial perlu dimanfaatkan untuk memberikan kesempatan akses terhadap modal lainnya, seperti modal finansial, modal fisik, modal alam dan modal manusia.

Akses terhadap modal finansial yang terbatas perlu untuk ditingkatkan melalui pembentukan lembaga keuangan mikro. Lembaga keuangan mikro akan dapat berjalan dengan baik ketika rasa saling mempercayai antar warga sangat tinggi. Lembaga keuangan mikro ini bukan merupakan lembaga baru yang dibentuk oleh orang dari luar komunitas tersebut, namun merupakan upaya memanfaatkan lembaga kesejahteraan tradisional yang sudah ada di masyarakat.

Peran perempuan juga menjadi salah satu harapan dalam pengembangan strategi nafkah berkelanjutan. Pemanfaatan ikatan sosial antar penduduk perempuan yang selama ini ada perlu untuk ditingkatkan sehingga memberi peluang akses terhadap modal finasial. Dukungan dari penduduk laki-laki (suami atau ayah) sangat menentukan. Kegiatan perempuan selama ini masih terbatas pada kegiatan reproduktif dengan curahan waktu yang cukup tinggi. Sedangkan, kontribusi perempuan dalam pendapatan rumah tangga masih terbatas. Tanpa adanya dukungan dari laki-laki, peningkatan peran perempuan nafkah rumah tangga menjadi terbatas. Ikatan sosial dan kerjasama antar penduduk perempuan sangat bergantung pada dukungan penduduk laki-laki. Bentuk dukungan dapat berupa pemberian informasi dan pemberian fasilitas bagi istri untuk melaksanakan kegiatan produktif seperti arisan, pelatihan, simpan pinjam dan sebagainya

\section{G. Kesimpulan}

Derempuan mempunyai peran dalam sistem nafkah rumah tangga. Kontribusi perempuan dalam nafkah rumah tangga diperoleh melalui kegiatan produktif yang mereka lakukan. Kegiatan tersebut, di antaranya, adalah keterlibatan perempuan dalam pemasaran hasil tangkapan dan keterlibatan dalam kegiatan pengolahan hasil tangkapan. Industri kecil di pedesaan ternyata mempunyai peran dalam meningkatkan kontribusi perempuan dalam nafkah rumah tangga mereka.

Alasan utama melakukan strategi nafkah ganda pada rumah tangga berbeda pada masing-masing lapisan. Pada rumah tangga lapisan atas, pola nafkah ganda merupakan strategi akumulasi modal dan lebih bersifat ekspansi usaha. Sedangkan pada lapisan menengah, pola nafkah ganda merupakan upaya konsolidasi untuk mengembangkan ekonomi rumah tangga. Sebaliknya pada lapisan bawah, pola nafkah ganda merupakan strategi bertahan hidup pada tingkat subsistensi dan sebagai upaya untuk keluar dari kemiskinan.

Strategi nafkah yang dilakukan oleh rumah tangga nelayan miskin terdiri atas strategi ekonomi dan strategi sosial. Strategi ekonomi dilakukan dengan cara melakukan pola nafkah ganda, pemanfaatan tenaga kerja rumah tangga dan migrasi. Sedangkan strategi sosial dilakukan dengan memanfaatkan ikatan kekerabatan yang ada. Kelembagaan kesejahteraan tradisional juga mempunyai peran yang penting bagi rumah tangga miskin dalam memenuhi kebutuhan hidupnya. Modal sosial mempunyai peran yang cukup penting dalam strategi nafkah rumah tangga miskin di Nagari Tiku Selatan. Modal sosial menjadi salah satu pokok perhatian dalam upaya penyusunan strategi nafkah berkelanjutan. Pembentukan lembaga keuangan mikro berbasis lembaga kesejahteraan tradisional merupakan salah satu solusi untuk mengatasi keterbatasan akses terhadap modal finansial. Lembaga keuangan mikro sudah seharusnya bukan merupakan lembaga baru, melainkan pemanfaatan lembaga kesejahteraan yang sudah mengakar pada masyarakat. Akses terhadap modal finansial ini perlu juga diimbangi dengan peningkatan terhadap modal manusia melalui pelatihan keterampilan teknis yang sesuai dengan potensi dan kebutuhan masyarakat. 


\section{Daftar Pustaka}

Bronstein, 2009. The Triple Strugle: War and Want, London.

Budiman, Arief, 2010. Pembagian Kerja Secara Seksual: Sebuah Pemahaman Sosiologis tentang Peran Wanita dalam Masyarakat, Gramedia, Jakarta.

Bungin, Burhan, 2004, Metodologi Penelitian Kualitatif:Aktualisasi Metodologis ke Arah Ragam Varian Kontemporer, Jakarta: PT. RajaGrafindo Persada.

Danim, Sudarwan, 2002, Menjadi Peneliti Kualitatif, Bandung: Pustaka Setia.

Ginkel, Rob van. 2007. Coastal Cultures: An Anthropology of Fishing and Whaling Traditions. Apeldoorn: Het Spinhuis Publishers

Hidayat, Wahyu. 2007. Wanita dalam Pembangunan. Dalam Majalah IImiah Fakultas Ekonomi Universitas Semarang Vol. 6 No. 3 Juli 2007, hal 43-46.

Keesing, Roger M. 1989. Antropologi Budaya: Suatu Perspektif Kontemporer. Jakarta: Erlangga

Kusnadi. 2000. Nelayan: Strategi Adaptasi dan Jaringan Sosial. Bandung: Humaniora Utama Press.

2001. Pangamba' Kaum Perempuan Fenomenal: Pelopor dan Penggerak Perekonomian Masyarakat Nelayan. Bandung: Humaniora Utama Press.

2003. Akar Kemiskinan Nelayan. Yogyakarta: LKiS.

2009. Keberdayaan Nelayan dan Dinamika Ekonomi Pesisir. Yogyakarta: Ar- Ruzz Media.

2010. "Kebudayaan Masyarakat Nelayan" dalam Makalah ini disampaikan dalam kegiatan JELAJAH BUDAYA TAHUN 2010, dengan tema "Ekspresi Budaya Masyarakat Nelayan di Pantai Utara Jawa", yang Diselenggarakan oleh Balai Pelestarian Sejarah dan Nilai Tradisional, Kementeian Kebudayaan dan Pariwisata, di Yogyakarta, tanggal 12-15 Juli 2010.

Leacock, 2008. Gender Planning and Development: Theory, Practice and Training, Routledge, London.

Moleong, Lexy, 2001, Metode Penelitian Kualitatif, Bandung: PT.Remaja Rosda Karya.

Mulyo, J. H dan Jamhari. 1998. Peranan Wanita Peningkatan Pendapatan dan Pengambilan Keputusan: Studi Kasus pada Industri Kerajinan Geplak di Kabupaten Bantul dalam Agro Ekonomi. Jurnal Sosek 5(1): 1-10

Neuman, W. Lawrence, 2006, Social Research Methods: Qualitative and Quantitative Approaches $6^{\text {th }}$ Edition, US: Pearson International Edition

Purwanti P., E.Y. Herawati dan A.R. Dani. 2004. Curahan Waktu dan Produktivitas Kerja Wanita Nelaydi Pedesaan Pantai KabupatenPasuruan. Jurnal IImu-ilmu Sosial Fakultas Perikanan Universitas Brawijaya Malang 16 (1):1-10.

Rogers, 2010. Working Women in South East Asia: Development, Suburdination and Emansipation, Open University Press, Philadelphia.

Sajogyo, Pudjieati, 2011. Peranan Wanita dalam Perkembangan Masyarakat Desa, Rajawali Press, Jakarta.

Santoso,Khairudin,2010.Sosiologi Gender,Nurcahaya,Yogyakarta.

Scott, C, 2008. Women's Work and family in Nineteenth Centery Europe, Comperative Studies, In Society and History.

Spradley, James P. 1997. Metode Etnografi. Yogyakarta: PT tiara Wacana

Suratiyah, Ken, dkk, 2008. Wanita, Kerja dan Rumah Tangga, Pengaruh Pembangunan Pertanian terhadap Peranan Wanita Pedesaan di DI Yogyakarta, PKK UGM, Yogyakarta.

Todaro, Michael P. 2000. Pembangunan Ekonomi di Dunia Ketiga. Edisi Ketujuh. Alih Bahasa Haris Munandar. Jakarta; Erlangga

Van Bemellen, Sita, 1995. Women's Issves Between Thee family and The Haousehold, Makalah Seminar ISI, 2-3 Nopember 1995, Ujung Pandang.

Widodo, Slamet. 2012. PERAN PEREMPUAN DALAM SISTEM NAFKAH RUMAH TANGGA NELAYAN dalam prosiding Seminar Nasional Kedaulatan Pangan dan Energi 2012, ISBN 978-602-19131-1-6 
Zamzami, Lucky. (2009). "Sistem Pengetahuan Lokal Nelayan Terhadap Teknologi Penangkapan Ikan pada Masyarakat Pasar Laban, Kecamatan Bungus Teluk Kabung, Kota Padang" dalam Jurnal FENOMENA Volume 07, Nomor 02, September 2009

Zamzami, Lucky. (2009). "Studi Kualitatif Dampak Perubahan Sosial terhadap Amalan Merantau di Kalangan Nelayan." Satu Kajian Kes di Kelurahan Purus, Kota Padang: UKM Malaysia: Tesis yang tidak dipublikasikan.

Zamzami, Lucky. 2010. Pemberdayaan Ekonomi Masyarakat Pesisir di Nagari Ampiang Perak, Sumatera Barat dalam Jurnal MIMBAR MIMBAR, Vol. XXVII, No. 1 (Juni 2011): 113-125 Terakreditasi' SK Dikti No. 64a/DIKTI/Kep/2010.

\section{Internet}

Astuti, Dwi. 2007. Diskusi Kelima : Perempuan Nelayan Dalam Ekonomi Pesisir : Tangguh Dibalik Bayang-Bayang http://ruraltalks.ihcs.or.id/?p=184, diakses tanggal 1 September 2013 jam 14.36.

http://www.sumbarprov.go.id/index.php Gubernur Sumbar dukung rencana Pembangunan Dermaga Tiku.

Suhartini, 2012. Peran Wanita Nelayan di dalam Keluarga, Rumah Tangga dan Masyarakat di Madura - Jawa Timur dalam repository.unej.ac.id/ handle/123456789/226, diakses tanggal 1 September 2013 jam 15.25 